DOI: 10.20472/IAC.2020.054.015

\author{
DILSAH BUSRA KARTAL \\ Fatih Sultan Mehmet Vakif University, Istanbul, Turkey
}

\title{
RECENT DEVELOPMENTS IN TURKISH LAW REGARDING THE SURNAME OF A MARRIED WOMAN
}

\begin{abstract}
:
According to Article 187 of the Turkish Civil Code, a married woman must change her surname upon marriage. The article only provides a married woman with the right to bear her own surname before the surname of her husband. This rule is not only in conflict with the Turkish Constitution but also with the international agreements to which Turkey became a party. The Turkish courts have changed their application of Article 187 in the last years. Practically, Article 187 is considered void by the courts but there is no amendment to the article so far. Even though the courts do not apply Article 187, administrative authorities adhere to it. Therefore, a woman who does not wish to bear a family name is forced to file a lawsuit to use this right. Unless Article 187 is amended, the problem cannot be fully solved. There are some amendment proposals but none of them are satisfying.
\end{abstract}

\section{Keywords:}

Surname of Married Women, Incorporeal Personality, Gender Equality, Turkish Family Law, Effects of a Marriage, Family Name, Surname

JEL Classification: K36, K41, K10 


\section{INTRODUCTION}

Identity is the qualities of a person that differentiateshim or her fromthe others ${ }^{1}$. These qualities include, among others, appearance, biography, ideas, abilities andinterests ${ }^{2}$. One of the most distinctive features of a person's identity is his or hername ${ }^{3}$. Thus, the name is a part of the personality. The name of a person is only complete with a surname. In Turkish law, Article 1 of the Surname Code statesthat every person must have a name and a surname. The right to have a surname is an absolute right which means that it is inalienable and unassignable 4 . According toArticle $27 / /$ of the Turkish Civil Code numbered 4721 (TCC), the change of a name can only be requested from a court when there is a justifiablecause. According to this article, as a general rule, a name and surname cannot be changed 5 . However, in Turkey, women cannot benefit fromsuchprotection. As a rule and by force of law, Turkish women must change their surname when they marry or get a divorce.

A person'ssurname is also called his or her family name as it relates such person to a certain family and ancestry ${ }^{6}$. Due to this aspect,surnames have more cultural and communal features than names and Turkey has a long patriarchal history and tradition. Therefore,the legal understanding of the "family name" by Turkish authorities is mostly shaped according to this background. However, the position of a woman in a marriage has changed within years following the economic and cultural changes in society and the Turkish legislative followed the agenda to amend all of the regulations violatingthe principle of gender equality. Although this agenda has been achieved considerably, the surname of a married woman remains to be an unsolved issue in Turkish law. This issue is viewed as a remnant of the old Turkish patriarchal tradition and culture ${ }^{7}$.

Patriarchy is a system which cannot be resolved only by way oflegal amendments, especially the amendments on the law in respect of surnames. One of the definitions of the patriarchy is "Social organization marked by the supremacy of the father in the clan or family, the legal dependence of wives and childrenand the reckoning of descent and inheritance in the male line ${ }^{8 \prime}$. As it can be deducted from such definition, as long as the descent is

\footnotetext{
${ }^{1}$ Cambridge English Dictionary. retrieved on 5/1/2020 from dictionary.cambridge.org/dictionary/english/identity.

${ }^{2}$ Haller, M. and Müller, B. (2008) Characteristics of Personality and Identity in Population Surveys: An Approach for operationalisation and Use to Explain Life Satisfaction. Bulletin de Méthodologie Sociologique. Vol. 99, pp. 5-33, N. 9. Retrieved on 5/1/2020 from journals.openedition.org/bms/2483.

${ }^{3}$ Hausheer, H. nndAebi-Müller, R. E. (2016) Das Personenrecht des SchweizerischenZivilgesetzbuches. 4th Edition, Bern, p. 289.

${ }^{4}$ Moroğlu, N. (2012) KadınınKimlikSorunu “KadınınSoyadı". TürkiyeBarolarBirliğiDergisi. Vol. 99, pp. 245-268, p. 247; Tacir, $\quad$ H. EvliKadınınKendiSoyadınıKullanmasıKonusundaAnayasaMahkemesininYaklaşımınınTemelHakveÖzgürlüklerBakı mındanDeğerlendirilmesi. Kadir Has ÜniversitesiHukukFakültesiDergisi. Vol. 1, Issue: 5, pp. 49-70, p. 51-52; Atasoy, H. (2015) EvliKadınınSoyadıSorunu "Anayasal” mı? Bireysel mi? UyuşmazlıkMahkemesiDergisi. Vol. 5, pp. 131-170, p. 134 (Soyadı).

${ }^{5}$ Atasoy, Soyadı, p. 137; Dural, M./Öğüz, T. (2016) TürkÖzelHukuku: KişilerHukuku. Vol. 2, $17^{\text {th }}$ Edition, Istanbul, p. 177; Hausheer and Aebi-Müller, p. 299.

${ }^{6}$ Moroğlu, p. 247.

${ }^{7}$ Dursun, E. (2018) TürkMedeniHukukundaKadınveÇocuğunSoyadı. Istanbul, p. 25; Erdem, M. (2019) AileHukuku. 2nd Edition, Ankara, p. 239.

${ }^{8}$ Merriam-Webster Dictionary. Retrieved on 6/1/2020 from merriam-webster.com/dictionary/patriarchy.
} 
through the male line, patriarchy will remain. If women are allowed to use their maiden name upon marriage this will limit the effects of patriarchy in this sense. However, the maiden name of a woman will still be of her own father's. Therefore, cultural patriarchy will still be there.

Nevertheless, an amendmentto the law isnecessary. Even though an amendment will not result in a sudden inexistence of patriarchy, these rules still constitute a violation of the principle of gender equality, which has many different aspects other than patriarchy ${ }^{9}$. It is stated in the general preamble of the TCC that one of the aims of the code was to establish gender equality in civil relations ${ }^{10}$. Except for the rules regarding the surname of a woman, this aim is achieved ${ }^{11}$.

The requirement for womento change their surnames has many practical disadvantages for them. If theymarryor get divorced, they must amend their personal details onall of their official and non-official documents such as their passports, driver's licenses, I.D. cards and credit cards $^{12}$. By being forced to change their surname, women are also forced to announce their marital status ${ }^{13}$. In this sense, they are not allowed to preservetheir privacy.Moreover, this issue also creates an identity problem for women ${ }^{14}$. Thus, the search for a solution not only aims to establish the gender equality but also aims to grant women the right to protect their identities.

\section{SOURCE OF THE PROBLEM: THE TURKISH CIVIL CODE}

\section{A. THE SURNAME OF A MARRIED WOMAN ACCORDING TO THE TURKISH CIVIL CODE}

In Turkish law, the regulations regarding the surname of a married woman had gone through changes in time. Article 153 of the former Turkish Civil Code numbered 743 (fTCC) regulated that a woman must use the family name of her husband. This Article did not allow a married woman to use her maiden name at all. In 1997, this Article was amended and the new Article 153 allowed a married woman to retain her surname along withher husband's surname. In 2002, the new TCC was passedand became effective in the same year. Article187 of the TCC regulates that, a woman shall acquireher husband's surname upon marriage, but she can also retain her surname before her husband's surname upon written request to the

\footnotetext{
${ }^{9}$ Oruç, M. (2016) EvliKadınınMünhasıranBekârlıkSoyadınıKullanabilmesi. TürkiyeAdaletAkademisiDergisi. Vol. 27, pp. 451-465, $\quad$ p. $452 ; \quad$ ErbekOdabaşı, $\quad$ Ö. $\quad$ (2017)

AnayasaMahkemesiveYargıtayKararlarıÇerçevesindeEvliKadınınSoyadı.

DokuzEylülÜniversitesiHukukFakültesiDergisi. Vol. 1. Issue. 19, pp. 43-109, p. 63; Atasoy, Soyadı, p. 147; Erdem, p. 239. On the other hand, some scholars state that prohibiting women from using only their maiden name does not violate the gender equality principle because this rule is in line with the cultural habits and prevents social disorder. Even though in the perspective of gender equality they differ from the general approach, these scholars are also in support of allowing women to be able to use their maiden name upon marriage. See: Hatemi, $H$. and KalkanOğuztürk, B. (2014) AileHukuku. $4^{\text {th }}$ Edition, Istanbul, p. 85-86.

${ }^{10}$ The preamble of the Turkish Civil Code. Retrieved on 5/1/2020 from tbmm.gov.tr/sirasayi/donem21/yil01/ss723m.htm.

${ }^{11}$ Moroğlu, p. 255.

${ }^{12}$ Moroğlu, p. 254; Oruç, p. 454; Tacir, p. 52; KılıçoğluYılmaz, K. (2014) KadınınBitmeyenSoyadıSorunu. Ankara BarosuDergisi. Vol. 4, pp. 581-592, p. 586; Atasoy, Soyadı, p. 146.

${ }^{13}$ Tacir, p. 52.

${ }^{14}$ Moroğlu, p. 254.
} 
marriage officerat the time of marriage or to thepopulation administration following the marriage ${ }^{15}$. The contents of the former Article 153 and the new Article 187 are the same. Therefore a woman must change her surname upon marriage. Since Article 187 is a mandatory rule, the spouses may not deviate from it ${ }^{16}$. However,that is not the end of the problem. According to Article 173, a woman must continue to use her formersurname (i.e. her maiden name)following thedivorce. Furthermore, if sheproves that she hasan interest in using the surname of her formerhusband and that such would not cause him any loss, she can askthe permissionof a courtto keep using his surname after the divorce ${ }^{17}$. In case there is a change in circumstances, the husband can request the revocation of this permission. This article forces a woman to change all of her official and non-official documents one more time.

In light of these articles, the principle of protection of a person'sname has only a limited application for women. Since a womanhas to use her husband's surname, she has to obey her husband's decisions that could affecthersurname. For example, according toArticle314 of the TCC, in case of an adoption of an adult, such adult can bear the surname of the adopter andif the adopted adult is a married man, the surname of his wife also changes accordingly ${ }^{18}$. If a manchanges his surname basing on a justifiable cause according to Article $27 / 1$ of the TCC, this also changes the surname of his wife ${ }^{19}$. On the contrary, even if she can prove a justifiable cause, a married woman cannot change hersurname (i.e. the surname of her husband) ${ }^{20}$.

\section{B. EXAMINATION OF ARTICLE 187 IN LIGHT OF THE TURKISH CONSTITUTION AND INTERNATIONAL AGREEMENTS}

Same as other law systems, the hierarchy of norms principle is present in the Turkish law as well.Article $11 /$ ll of the Turkish Constitution (TC) dated $1982^{21}$ states that "Laws shall not be contrary to the Constitution." Therefore, the constitution is at the top of the hierarchy of norms ${ }^{22}$. In the TC there are various rules which regulate gender equality. For instance,Article10/II of the TC states; "Men and women have equal rights. The State has the

\footnotetext{
15 If she decides to use her right subsequently it is not limited with time and can always be used during the marriage (Atasoy, Soyadı, p. 143; KılıçoğluYılmaz, p. 138). TCC is a translation of the Swiss Civil Code (ZGB). However, Article 187 is the former version of corresponding Article 160 of ZGB. In 2013, Article 160 was amended. According to the new regulation, every spouse keeps using their surname upon marriage. However, every spouse is allowed to use the surname of the other spouse. But spouses are not allowed to have more than one surname anymore. For detailed information see: Bühler, R. (2014) Art. 160. Basler Kommentar: Zivilgesetzbuch I. $5^{\text {th }}$ Edition, Ed. Honsell, H. et. al., Basel, p. 983-986; Hausheer and Aebi-Müller, p. 293-294.

${ }^{16}$ ÖcalApaydın,

B.

(2015)

Son

YargıKararlarışığındaKadınınSoyadıMeselesiÇözümeKavuşturulmuşmudur?.InönüÜniversitesiHukukFakültesiDerg isi. Vol. 2 Issue: 6, pp. 425-458, p. 436; Erdem, p. 240; Dural, M./Öğüz, T./Gümüş, M. A. (2016) TürkÖzelHukuku: AileHukuku. Vol. 3, $11^{\text {th }}$ Edition, Istanbul, p. 158.

17 This permission can be asked during the divorce process or within one year after the divorce is finalized (Article 178 of TCC). See also: Moroğlu, p. 256.

${ }^{18}$ Moroğlu, p. 254; Atasoy, Soyadı, p. 146.

${ }^{19}$ Moroğlu, p. 254; Atasoy, Soyadı, p. 146.

${ }^{20}$ Atasoy, Soyadı, p. 137.

21 See for the English translation of the Turkish Constitution. Retrieved on 6/1/2020 from global.tbmm.gov.tr/docs/constitution_en.pdf.

${ }^{22}$ Kuluçlu, E. (2008) TürkHukukSistemindeNormlarHiyerarşisiveSayıştayDenetimineEtkileri. SayıştayDergisi. Vol. 71 , pp. 3-22, p. 4.
} 
obligation to ensure that this equality exists in practice". Additionally, according to Article 41/l; "Family is the foundation of the Turkish society and based on the equality between the spouses".

The TC also covers the protection of personality. Article 12 regulates that; "Everyone possesses inherent fundamental rights and freedoms, which are inviolable and inalienable. The fundamental rights and freedoms also comprise the duties and responsibilities of the individual to the society, his/her family, and other individuals",and Article 17/Iregulates that;"Everyone has the right to life and the right to protect and improve their corporeal and spiritual existence".

In Turkish law, according to Article 90/V of the TC, international agreements regarding the fundamental rights and freedoms prevail over laws. In this sense, some international agreements form the second layerof the hierarchy ${ }^{23}$. The rule statedin Article $90 / \mathrm{V}$ is as follows: "In the case of a conflict between international agreements, duly put into effect, concerning fundamental rights and freedoms and the laws due to differences in provisions on the same matter, the provisions of international agreements shall prevail'. Turkey became a party tonumerousinternational agreements. Some of them include rules about gender equality as well. Therefore, in case there is a conflict betweendomestic laws andsuchagreements, the latter prevails.

In 1954 Turkey became a party tothe European Convention on Human Rights (Convention). According toArticle 8 of the Convention; "1. Everyone has the right to respect for his private and family life, his home and his correspondence. 2. There shall be no interference by a public authority with the exercise of this right except such as is in accordance with the law and is necessary in a democratic society in the interests of national security, public safety or the economic well-being of the country, for the prevention of disorder or crime, for the protection of health or morals, or for the protection of the rights and freedoms of others."and theArticle 14 states; "The enjoyment of the rights and freedoms set forth in this Convention shall be secured without discrimination on any ground such as sex, race, colour, language, religion, political or other opinion, national or social origin, association with a national minority, property, birth or other status."

In 2016, Protocol No. 7 to the Convention for the Protection of Human Rights and Fundamental Freedoms (Protocol)also came into force in Turkey. According toArticle 5 of the Protocol; "Spouses shall enjoy equality of rights and responsibilities of a private law character between them, and in their relations with their children, as to marriage, during marriage and in the event of its dissolution. This article shall not prevent States from taking such measures as are necessary in the interests of the children."

Turkey is also a party toConvention on the Elimination of All Forms of Discrimination against Women (CEDAW) and International Covenant on Civil and Political Rights (ICCPR). Article 16/I of the CEDAW states that; "States Parties shall take all appropriate measures to eliminate discrimination against women in all matters relating to marriage and family relations and in particular shall ensure, on a basis of equality of men and women: ...g) The same personal rights as husband and wife, including the right to choose a family name, a profession and an occupation." andaccording to Article23/IV of theICCPR; "States Parties to the present Covenant shall take appropriate steps to ensure equality of rights and responsibilities of

${ }^{23}$ Kuluçlu, p. 5. 
spouses as to marriage, during marriage and at its dissolution. In the case of dissolution, provision shall be made for the necessary protection of any children."

All of the regulations mentionedabove are in favor of allowing a woman to choose her surname freely and they all prevail overArticle187. However, in legal practice courts did not allow a married woman to bear only her maiden name by notusing her husband's surname. Even the Turkish Court of Appeals blocked the way to this freedom. Since Turkey is bound by the decisions of the European Court of Human Rights (ECHR), this issue came before the ECHR various times. The ECHR ruled in favor of the applicants and in time this approach had an impact on the domesticcourts. Before getting into that, we would like to first address the important decisions of theECHR regarding the issue.

The most famous case which came before the ECHR regarding the surname of a Turkish woman is the ÜnalTekeli vs. Turkey ${ }^{24}$. AytenÜnalTekeli was married to her husband in 1990. Even though she continued to use her maiden name in her professional life, she had to use her husband's surname in anyofficial paper. At the time of their marriage,thefTCC did not even allow a woman to use both surnames. Therefore,she applied before a court to be able to use her maiden namein 1995. The first instance court rejected the case stating that the claim did not have merit under the fTCC. When she appealed, the Turkish Court of Appeals upheld the first instance court's decision. After the amendment of Article 153 in 1997, she stated that this amendment did not satisfy her demand and applied tothe ECHR. The ECHR judgment was in favor of the applicant. The court reasonedthat Article 14 of the Convention offersprotection against any discrimination in the enjoyment of the rights and freedoms guaranteed under the Convention.Article 8 of the Convention protects the private lifeand the family life of a person. A person'ssurname as a part of the person's identity and his or her link to a family also falls within the scope ofArticle 8 . If there is an objective and reasonable justification, a different treatment would not be considered as a violation of Article 14. It is also possible to establish a different treatment which is founded on an objective assessment of essentially different factual circumstances and which, being based on the public interest, strike a fair balance between the protection of the interests of the community and respect for the rights and freedoms safeguarded by the Convention. According to the Court, refusing to allow women to use their maiden name is a difference in treatment basing on genderand there is no objective and reasonable justification for this difference. Finally, the Court ruled that the difference in treatment with regards to the surname of the women constitutes a violation of Article 14 taken in conjunction with Article 8.

Even after this judgment, the problem in legislation and practice continued to exist. This resulted in even more applications to the ECHR. In 2013, three cases on the same topic came before the ECHR. The first case wasLeventoğluAbdulkadiroğlu vs. Turkey case ${ }^{25}$. It was a similar case to ÜnalTekeli vs. Turkey and the Court made a similar judgment indicating that there is a violation of Article 14 taken in conjunction with Article 8. This case was followed by TuncerGüneş vs. Turkey ${ }^{26}$ and TanbayTüten vs. Turkey ${ }^{27}$ cases and similar judgments were made for each of them.

\footnotetext{
24 Case of ÜnalTekeli vs. Turkey. Application No: 29865/96 dated 16/11/2004. Retrieved on 6/1/2020 from hudoc.echr.coe.int/eng\#\{\%22itemid\%22:[\%22001-67482\%22]\}.

${ }^{25}$ Case of LeventoğluAbdulkadiroğlu vs. Turkey. Application No: 7971/07 dated 28/5/2013. Retrieved on 6/1/2020 from hudoc.echr.coe.int/eng\#\{\%22itemid\%22:[\%22001-119957\%22]\}.

26 Case of TuncerGüneş vs. Turkey. Application No: 26268/08 dated 3/09/2013. Retrieved on 6/1/2020 from juridique.defenseurdesdroits.fr/doc_num.php?explnum_id=7278.
} 


\section{DEVELOPMENTOF THETURKISHDOMESTIC COURT DECISIONS REGARDING THE SURNAME OF A MARRIED WOMAN}

\section{A. GENERAL OVERVIEW}

The problem with regards to the surname of women became an issue before the all three degrees of the Turkishdomestic courts. Married women who wishto use their own surname first made their requestto first instance courts. The defendant in suchcases is the relevant district populationadministration. Some first instance courts ruled in favor of the claimants while others ruled according toArticle 187 of the TCC (and Article153 of the fTCC). Some decisions that are in favor are finalized as the population administration did not appeal. But in most cases, the population administration chose to appeal. In suchcases, the Court of Appeals has ruled against the claimant and reversed the judgments. Constitutionality of Article 187 (and Article 153) was disputed before the Constitutional Court (CC) twice. However, in both cases, the CC ruled that Article 187 (and Article153) was not in violation of the TC.

\section{B. THE CONCRETE NORM CONTROL DECISIONS OF THE CONSTITUTIONAL COURT}

In 1998, after a first instance court applied to the CC with the claim to annul Article 153 of the fTCC on grounds of violation of gender equality, the CC ruled that, if there are justifiable reasons for a difference in treatment, this treatment does not violate equality principle. Article 153 regulates a different treatment on grounds of public order and public welfare. It protects the family union by handing the family name down from generation to generation. The lawmaker gave priority to one of the spouses to protect the family union. The married women are allowed to keep their own surnamesalong with the surnames of their husbands. Finally, the CC ruled that there was no violation of the TC and refused to annul Article $153^{28}$.

In 2011, Article 187 wasonce again discussed by the CC uponthe claim of annulment on the grounds of unconstitutionality. This time three different first instance courts applied to the $\mathrm{CC}$ and they based their claims on international agreements and theECHR decisions regarding the issue. However, the $\mathrm{CC}$ maintained its former opinionand rejected the case on the same grounds as previous case.

In Turkish law, according to Article 152 of the TC; "No claim of unconstitutionality shall be made with regard to the same legal provision until ten years elapse after publication in the Official Gazette of the decision of the Constitutional Court dismissing the application on its merits."Therefore, it is not possible to bring this issue before the CC with the demand for annulment until 2021. However, as it will be explained below, as of 2012, individual application right to the CC is granted to people. This development changed the course of the judgments.

\footnotetext{
27 Case of TanbayTüten vs. Turkey. Application No: 38249/09 dated 10/12/2013. Retrieved on 6/1/2020 from hudoc.echr.coe.int/fre\#\{\%22itemid\%22:[\%22001-138892\%22]\}.

28 Constitutional Court decision dated 29/9/1998 numbered 1997/61 E. 1998/59 K. Retrieved on 6/1/2020 from kararlaryeni.anayasa.gov.tr/Karar/Content/8d95104c-3cad-4461-bae2-

a1b1a3b59dc8?excludeGerekce=False\&wordsOnly=False.
} 


\section{THE INDIVIDUAL APPLICATIONS TO THE CONSTITUTIONAL COURT}

As of the amendment of Article148 of theTC in 2010, whichcame into force in 2012, Turkish law was introduced to theindividual application to the CC. The individual application is designed as the last resort for the applicant who believes his or her fundamental rights are violated $^{29}$. Therefore, the applicant must exhaust all legal remedies before submitting an individual application. The details of the individual application process are beyond the scope of this study. However, to make our following statements more understandable, it is necessary to explain some of the basic principles of this remedy.

Every person whose fundamental rights and freedoms are violated by a public authority has the right to file an individual application to the $\mathrm{CC}^{30}$. Normally, it is not possible to file an individual application regarding the legislation. But if the violation is a result of a law that conflicts with the rules of theTC about the fundamental rights and freedoms, individual application way is open ${ }^{31}$. In such a case, the CC can demand from the General Council to review and annul the relevant legal rule ${ }^{32}$. In the case of the Article187, as explained above, this way is closed until 2021. Apart from the annulment claim to the General Council, the CC is obliged to make a judgment to resolve the case. In this sense, if the CC rules that there is a violation, the case is sent back to the relevant lower court for retrial. This time the lower court is obliged to make its decision in accordance withthis judgment ${ }^{33}$. But thejudgment of the CC does not by itself annul the relevant law.

After the establishment of the individual application, there had been three cases $^{34}$ regarding Article187. In 2013, the first case was brought before the CC by the applicant SevimAkatEşki. She exhausted all legal remedies to be able to use her own surname upon marriage with no success. The $\mathrm{CC}$ handled the case different from the former concrete norm control cases. The CC examined the issue in light of Article17 of theTC which regulates the protection of the corporeal and incorporeal personality of a person. The $\mathrm{CC}$ stated that Article8 of the Convention corresponds to Article17 of theTC and according to these articles,the surname constitutes a part of the incorporeal personality. In this sense, women should also benefit from the protection provided for the surname. The fact that women are not allowed to bear their own surnames is a violation of these articles. As Article 90/V of the TC regulates that international agreements on fundamental rights and freedoms prevail over domestic laws, Article8 of the Convention can be applied directly by the domestic courts. In the end, the CC sent the case back to the lower court for retrial ${ }^{35}$. This judgment was followed

\footnotetext{
29 Aydın, Ö. D. (2011) TürkAnayasaYargısındaYeni Bir Mekanizma: AnayasaMahkemesi'neBireyselBaşvuru. Gazi ÜniversitesiHukukFakültesiDergisi. Vol. 4, Issue XV, pp. 121-170, p. 126.

30 Aydın, p. 134, Atasoy, H. (2012) TürkHukukundaBireyselBaşvuruYolu. TürkiyeAdaletAkademisiDergisi. Vol. 9 , pp. 71-89, p. 72 (Bireysel).

${ }^{31}$ Aydın, p. 141; Atasoy, Bireysel, p. 89.

32 Aydın, p. 144; Atasoy, Bireysel, p. 89.

${ }^{33}$ Aydın, p. 162-163.

34 There had been one more application but it was rejected on grounds of procedural deficiency. The applicant of that case had not exhausted all legal remedies required for the individual application. See: Application of Ayşe SenaSezgin Arslan. Application no: 2014/13367. Judgment date: 15/4/2015. Retrieved on 8/1/2020 from kararlarbilgibankasi.anayasa.gov.tr/BB/2014/13367.

35 Application of SevimAkatEşki. Application no: 2013/2187. Judgment date: 19/12/2013. Retrieved on 8/1/2020 from kararlarbilgibankasi.anayasa.gov.tr/BB/2013/2187.
} 
by two more similar decisions of theCC ruling that there is a breach of Article17 of the TC and Article8 of the Convention ${ }^{36}$.

\section{DEVELOPMENT OF THE DECISIONSOF THE COURT OF APPEALS}

Before the individual application way was established, decisions ofthe Turkish Court of Appeals(TCA) were to the detriment of the claimants. For example, in 2012, the TCAhad ruled that in light of Article187, it is not legally possible for a married woman to use only her maiden name. The TCA reasoned its decision by the fact that the CC had refused to annul Article187 and stated that this article did not violate the Constitution. As a result of this rejection, the domestic courts are bound by the decision of theCC and thus by Article 187. According to the TCA, even though in ÜnalTekeli vs. Turkey case, it was ruled that Article187 violated Article8 of theConvention,Article187 isvalid until it is amended. The TCA also stated that, according to the TCC, family union and integrity continues with the surname of the husband. A contrary court decision,therefore, violates this principle and public order ${ }^{37}$.Up until 2015, most of the decisions of the TCA were similar ${ }^{38}$. Even after the decisions of the CC in individual application cases, the TCA resisted allowing women to use only their maiden names.

In 2015, the General Chamber of Law of theTCA (Chamber) rendered a decision that changed the approach of both the other chambers of theTCA and thefirst instance courts. The Chamber stated that name and surname are the parts of the incorporeal personality regulated under Article17 of the TC. The Chamber also referred to the judgments of theECHR on similar cases and stated that the surname is accepted within the concept of private life according to Article8 of the Convention. In this sense, not allowing a woman to use only her own surname is a violation of Article 14 of Convention taken in conjunction with Article 8. Moreover, the Chamber stated that a family name is not effective in maintaining the family union. If the family union is not referred with a common surname, it does not result in important and concrete problems for the spouses or third parties. Possible problems that might arise in exercising civil registration services can be solved by technical regulations. Finally, the Chamber ruled that, according to Article 90/ $\mathrm{V}$ of theTC, if a law contradicts with an international agreement, the latter prevails. Therefore, it must be accepted that Article 187 is indirectly annulled and the women are allowed to use their maiden name even if they are married. The women are not required to have a justifiable reason to file a lawsuit with this claim ${ }^{39}$.

The decision of the Chamber is not legally binding for theTCA and other courts. However, in practice, after this decision, other chambers of theTCA, changed their consistent application

36 For these decisions see: Application of GülsimGenç. Application no: 2013/4439. Judgment date: 6/3/2014. Retrieved 8/1/2020 from kararlarbilgibankasi.anayasa.gov.tr/BB/2013/4439. Application of NeşeAslanbayAkbıyık. Application no: 2014/5836 Judgment date: 16/4/2015. Retrieved on 8/1/2020 from kararlarbilgibankasi.anayasa.gov.tr/BB/2014/5836.

${ }^{37}$ TCA 2nd Chamber of Law (CoL), 2011/7737 E. 2012/16695 K. Dated 18/6/2012. Retrieved on 9/1/2020 from lexpera.com.tr.

${ }^{38}$ For similar decisions see: TCA 18th CoL, 2010/6750 E. 2010/10314 K. Dated 6/7/2010; TCA 2nd CoL, 2013/6920 E. 2013/26077 K. dated 12/11/2013; TCA 2nd CoL, 2012/2319 E. 2013/4523 K. Dated 21/2/2013; TCA 2nd CoL, $2014 / 16089$ E. $2014 / 23993$ K. Dated 27/11/2014. All of the decisions are retrieved on $9 / 1 / 2020$ from lexpera.com.tr.

39TCA General Chamber of Law, 2014/2-889 E. 2015/2011 K. Dated 30/9/2015. Retrieved on 9/1/2020 from lexpera.com.tr. 
of Article 187. The new decisions are in favor of the claimant who wants to use her own surname and the decision of the Chamber is explicitly mentionedin these judgments ${ }^{40}$.

\section{THE CURRENT SITUATION IN PRACTICE}

Followingthe decisions of the General Chamber and subsequently, of theTCA, Turkish women are practically allowed to use only their maiden name upon marriage. However, they cannot use this right directly. Asthe Parliament has not yet amendedArticle 187, the administrative authorities adhere to this article. Thus, a married woman who does not want to use her husband's surname cannot achieve this purpose at the time of the marriage. At that time, her best option is to use her ownsurname in front of the surname of her husband. After that, she is supposed to file a lawsuit with this claim. According to theTCA, the defendants must be both the relevant population administration and the husband ${ }^{41}$. After the first instance court renders a decision in favor of the claimant, she can use this decision to change her surname in the population administration. However, this practice is not sustainable due to its exhaustive and costly process ${ }^{42}$. It is a very indirect and dissuasive way to use a right. It is not logical and practical to apply a so-called annulled law and then undo its results only after a court decision. There is also no steady protection for the right to a surname as it is always possible for the courts to change their mind on the issue and return to the old practice. As there is no amendment tolaw, this practice also carries the risk of taking over the power of legislation ${ }^{43}$. Therefore, the problem of surname must be solved by the Parliament with legislative action.

\section{THE PROPOSALS FOR THE AMENDMENT OF ARTICLE 187}

As the issue of the surname can only be fully solved by a legislative action there have been several amendment proposals submitted to the Parliament but none of them have passed into law ${ }^{44}$. The proposals differ in context. According to one proposal ${ }^{45}$, spouses should choose the family name together between their own surnames. The spouse whose surname is not chosen as the family name should be able to use his or her own surname before the family name. In my opinion, this proposal does not provide a suitable solution to the

\footnotetext{
40 See for example: TCA 2nd CoL, 2016/22056 E. 2017/12849 K. Dated 16/11/2017; TCA 2nd CoL 2015/24244 E. 2016/3893 K. Dated 2/3/2016; TCA 2nd CoL 2015/20964 E. 2016/3188 K. Dated 23/2/2016; TCA 2nd CoL 2015/21685 E. 2016/2321 K. Dated 12/2/2016. All of the decisions are retrieved on 9/1/2020 from lexpera.com.tr. ${ }^{41}$ TCA 2nd CoL, 2016/795 E. 2016/8755 K. Dated 28/4/2016. Retrieved on 10/1/2020 from lexpera.com.tr. The requirement to engage the husband in the lawsuit as a defendant is criticized in the doctrinal level. See: ErbekOdabaşı, p. 100.

42 The claimant (the married woman) should bear the costs for the lawsuit (Oruç, p. 462).

${ }^{43}$ Oruç, p. 459

44 See for example: www2.tbmm.gov.tr/d23/2/2-0332.pdf; www2.tbmm.gov.tr/d24/2/2-0216.pdf; www2.tbmm.gov.tr/d22/2/2-0407.pdf; www2.tbmm.gov.tr/d24/2/2-0917.pdf; www2.tbmm.gov.tr/d24/2/2-1300.pdf. All of the proposals are retrieved on 19/1/2020. There was actually one more proposal from the Ministry of Justice but it is no more available online. This means that the Ministry of Justice does not have any current focus on the issue. Therefore we preferred not to examine this proposal. For more information about this proposal see: Ayan, S. (2012)

AnayasaMahkemesiKararlarıveÇocuklarileKadınınSoyadınallişkinDeğişiklikTasarısıTaslağılşığındaSoyadının İlk KezEdinilmesi, KendiliğindenDeğişmesiveDeğiştirilmesi. Gazi ÜniversitesiHukukFakültesiDergisi. Vol. 16, Issue: 4, pp. 19-90, p. 70-74.

${ }^{45}$ www2.tbmm.gov.tr/d22/2/2-0407.pdf. Retrieved on 19/1/2020.
} 
problem. First of all, as explained above, the surname should be protected as part of the identity. This protection is necessary for both men and women. The way to achieve this purpose is to let people decide as to whether they wish to bear a family name or not. Therefore, the lawmaker should dispose of the compulsion to bear a family name.

According to the other proposal ${ }^{46}$, as a rule, a woman should maintain her maiden name upon marriage but be allowed to bear the surname of her husband after her surname as well ${ }^{47}$. In our opinion, this proposal is far from the reality of Turkish marriages and also very limiting. Most of the Turkish women wish and are pleased to bear a family name. Thus, disposing of the family name as the basic principle is an extreme measure. Because this way, in practice the rule will become the exception. This proposal also prevents a woman from bearing only the surname of her husband. Therefore, even if she prefers to change her surname completely, she will not be allowed to do that. This is an unnecessary limitation for a family union.

According to another proposal ${ }^{48}$, upon written notification spouses should be allowed to choose between bearing only their surnames, the surname of the other spouse or their own surname before the family name. Another similar proposal ${ }^{49}$ suggests that spouses should have the right to agree on using a common surname. Every spouse should be able to bear only the other spouse's surname, his or her surname before the common surname or only the common surname ${ }^{50}$. Although these proposalsare better than the others, they are incomplete. They do not regulate the results in case the spouses do not make any agreement on the family name.

The last proposal ${ }^{51}$ in this regard suggests that a woman should bear the surname of her husband. But she should also be able to bear either her surname before his husband's or only her surname. When spouses agree on (another) surname, they should be allowed to use it together. In our opinion, this proposal is more agreeable than others. Because this proposal regulates the family name as a rule but does not compel spouses to bear it. However, there is one problem with this proposal. As mentioned above, according to Article $27 / /$ of theTCC, the surname can only be changed when there is a justifiable cause. However, this proposal allows spouses to agree on using another surname than their own as the family name even if there is no justifiable cause for this change.

\section{CONCLUSION}

As explained above, in Turkish law, according to Article 187 of theTCC, the women must change their surnames upon marriage. Their only legal right in this sense is bearing their own surnames before the surnames of their husbands. This rule conflicts with theTC and the international agreements to which Turkey became a party. Turkish courts had adhered

\footnotetext{
${ }^{46}$ www2.tbmm.gov.tr/d24/2/2-0216.pdf. Retrieved on 19/1/2020.

47 This proposal is very similar to Article 160 of ZGB. However,Article 160 also allows a man to bear the surname of her wife after his own surname. In this sense, Article 160 has a gender-free wording. On the other hand, this proposal handles the issue only for the women.

48 www2.tbmm.gov.tr/d23/2/2-0332.pdf. Retrieved on 19/1/2020.

49 www2.tbmm.gov.tr/d24/2/2-1300.pdf. Retrieved on 19/1/2020.

${ }^{50}$ According to this proposal, the spouses are allowed to agree on a different surname than their own surnames as the common surname of the family union.

51 www2.tbmm.gov.tr/d24/2/2-0917.pdf. Retrieved on 19/1/2020.
} 
toArticle 187 (andformer Article 153) strictly. However, in recent years, in light of the judgments of theECHR and theCC, the course of the judgments has changed. Currently, the women are allowed to bear just their own surnames only after filing a lawsuit with this claim. Therefore, this problem is not fully solved yet.

The surname of the married Turkish women is an ongoing problem that needs a legislative solution. After reviewing all of the proposals that we had accessed, we concluded that none of them are satisfying. Therefore, there need to be more efforts to solve the problem with a suitable and fair amendment. In our opinion, bearing a family name should be the rule and the lawmaker should allow the spouses to choose the family name between their own surnames. If there is no choice it is suitable to accept the surname of the husband as the family name. However, the family name should not be compulsory. Therefore, spouses should have the right to bear either only their surnames or their surnames before the family name. There should also be an amendment to Article 173 of theTCC that regulates the surname of the women upon divorce. The principle of maintaining the current surname should be regulated in that article as well. We believe this solution will establish a fair balance between the interest of the spouses and also be in line with the cultural background and expectations.

\section{REFERENCES}

Atasoy, H. (2015) EvliKadınınSoyadıSorunu "Anayasal" mı? Bireysel mi? UyuşmazlıkMahkemesiDergisi. Vol. 5, pp. 131-170 (Soyadı).

Atasoy, H. (2012) Türk Hukukunda Bireysel Başvuru Yolu. Türkiye Adalet Akademisi Dergisi. Vol. 9, pp. 71-89 (Bireysel).

Ayan,

S.

AnayasaMahkemesiKararlarıveÇocuklarileKadınınSoyadınailişkinDeğişiklikTasarısıTaslağılşığın daSoyadının İlk KezEdinilmesi, KendiliğindenDeğişmesiveDeğiştirilmesi. Gazi ÜniversitesiHukukFakültesiDergisi. Vol. 16, Issue: 4, pp. 19-90.

Aydın, Ö. D. (2011) Türk Anayasa Yargısında Yeni Bir Mekanizma: Anayasa Mahkemesi'ne Bireysel Başvuru. Gazi Üniversitesi Hukuk Fakültesi Dergisi. Vol. 4, Issue XV, pp. 121-170.

Bühler, R. (2014) Art. 160. Basler Kommentar: Zivilgesetzbuch I. $5^{\text {th }}$ Edition, Ed. Honsell, H. et. al., Basel, pp. 983-986.

Cambridge English Dictionary. retrieved on 5/1/2020 from dictionary.cambridge.org/dictionary/english/identity.

Dural, M. and Öğüz, T. (2016) TürkÖzelHukuku: KişilerHukuku. Vol. 2, 17 th Edition, Istanbul.

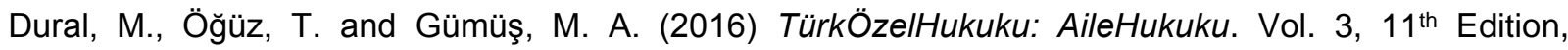
Istanbul.

Dursun, E. (2018) Türk Medeni Hukukunda Kadın ve Çocuğun Soyadı. Istanbul.

ErbekOdabaşı, Ö. (2017) AnayasaMahkemesiveYargıtayKararlarıÇerçevesindeEvliKadınınSoyadı. DokuzEylülÜniversitesiHukukFakültesiDergisi. Vol. 1. Issue. 19, pp. 43-109. 
Erdem, M. (2019) AileHukuku. $2^{\text {nd }}$ Edition, Ankara.

Haller, M. and Müller, B. (2008) Characteristics of Personality and Identity in Population Surveys: An Approach for operationalisation and Use to Explain Life Satisfaction. Bulletin de Méthodologie Sociologique. Vol. 99, pp. 5-33. Retrieved on 5/1/2020 from journals.openedition.org/bms/2483.

Hatemi, H. and KalkanOğuztürk, B. (2014) AileHukuku, 4th Edition, Istanbul.

Hausheer, H. and Aebi-Müller, R. E. (2016) Das Personenrecht des SchweizerischenZivilgesetzbuches. $4^{\text {th }}$ Edition, Bern.

KılıçoğluYılmaz, K. (2014) KadınınBitmeyenSoyadıSorunu. Ankara BarosuDergisi. Vol. 4, pp. 581-592.

Kuluçlu, E. (2008) Türk Hukuk Sisteminde Normlar Hiyerarşisi ve Sayıştay Denetimine Etkileri. Sayıştay Dergisi. Vol. 71, pp. 3-22.

Merriam-Webster Dictionary. Retrieved on 6/1/2020 from merriam-webster.com/dictionary/patriarchy.

Moroğlu, N. (2012) KadınınKimlikSorunu "KadınınSoyadı". TürkiyeBarolarBirliğiDergisi. Vol. 99, pp. 245-268.

Oruç, M. (2016) EvliKadınınMünhasıranBekârlıkSoyadınıKullanabilmesi. TürkiyeAdaletAkademisiDergisi. Vol. 27, pp. 451-465.

ÖcalApaydın,

B.

Son

YargıKararlarılşığındaKadınınSoyadıMeselesiÇözümeKavuşturulmuşmudur?

InönüÜniversitesiHukukFakültesiDergisi. Vol. 2, Issue: 6, pp. 425-458.

Tacir,

$\mathrm{H}$.

EvliKadınınKendiSoyadınıKullanmasıKonusundaAnayasaMahkemesininYaklaşımınınTemelHakv eÖzgürlüklerBakımındanDeğerlendirilmesi. Kadir Has ÜniversitesiHukukFakültesiDergisi. Vol. 1, Issue: 5, pp. 49-70. 